BMJ Open Sport \& Exercise Medicine

\section{Sports injury and illness incidence among South Korean elite athletes in the 2018 Asian Games: a single- physician prospective study of 782 athletes}

To cite: Lhee S-H, Jain $\mathrm{R}$ Madathur Sadasivam M, et al. Sports injury and illness incidence among South Korean elite athletes in the 2018 Asian Games: a singlephysician prospective study of 782 athletes. BMJ Open Sport \& Exercise Medicine 2021;7:e000689. doi:10.1136/ bmjsem-2019-000689

Accepted 11 June 2020

Check for updates

(C) Author(s) (or their employer(s)) 2020. Re-use permitted under CC BY-NC. No commercial re-use. See rights and permissions. Published by BMJ.

${ }^{1}$ Orthopedic Surgery, CM General Hospital, Seoul, Korea (the Republic of)

2Department of Mechanical Engineering, KAIST, Daejeon, Korea (the Republic of)

${ }^{3}$ Orthopedic Surgery, CM General hospital, Seoul, Korea (the Republic of)

${ }^{4}$ Medical and Science, Korean Sport \& Olympic Committee, Jincheon-gun, Chungcheongbuk-do, Korea (the Republic of)

${ }^{5}$ Orthopaedics, CM Hospital of Korean Olympic Committee Jincheon National Training Center, Cheonan-si, Chungcheongnam-do, Korea (the Republic of)

Correspondence to Dr Sang-Hoon Lhee sanghoon.lhee@gmail.com

\section{ABSTRACT}

Objective The increasing incidence of sports injury among athletes calls for systemic surveillance of injuries and illnesses in this field to develop preventive measures. The patterns of injuries and illnesses that occurred among Korean athletes during the 2018 Asian Games held in Indonesia were studied.

Methods We recorded the occurrence of all injuries and illnesses reported to the chief medical officer, coordinated with the help of an instant social messaging application in real time.

Results A total of 782 elite athletes participated in 46 sporting events. A total of 141 (18.03\%) injuries were recorded, with 121 (15.47\%) athletes suffering at least one injury. Out of 141 injuries 80 (56.74\%) were in male athletes and $61(43.26 \%)$ were in female athletes. The highest number of injuries was seen among sport climbing athletes ( $n=10,71.43 \%)$, followed by sepak takraw. A total of $16(11.35 \%)$ injuries were expected to prevent athletes from participation in competition/training. Most of the injuries occurred during training (46.10\%), with lower lumbar spine being the most common part injured. A total of $209(26.72 \%)$ illnesses were reported, with at least one illness in $170(21.73 \%)$ athletes. The incidence among female athletes $(26.90 \%)$ was comparable with that of male athletes (26.90\%). Maximum illness rate was reported in table tennis (100\%). The most common system involved was gastrointestinal ( $n=93,44.49 \%)$, followed by respiratory $(n=53,25.36 \%)$. Environmental factors were causative in 111 athletes $(53.11 \%)$ and infection in 79 (37.79\%). Illnesses resulted in loss of at least 1 day among $30(14.35 \%)$ athletes.

Conclusion Overall $15.47 \%$ of athletes suffered at least one injury and $21.73 \%$ suffered at least one illness; the incidence of injury and illness varied depending on the type of sports.

\section{INTRODUCTION}

Participation in sporting activities is important for all age groups to maintain health and for many other reasons, such as pleasure, socialisation and competition. Regular involvement

\section{Summary}

Injury and illness patterns among the Korean athletes who participated in the Asian Games were studied by a single physician using electronic media in real time and thus uniformity in reporting can be expected.

- We recorded an overall injury rate of 18 per 100 athletes, with male athletes at slightly higher risk of getting injured than female athletes.

- The rate of injury was higher compared with previous Olympics reports.

- Our statistics may reveal the actual risk of injury to athletes since it is based on a single-physician report.

- Training injuries were more common, implying the necessity of strict enforcement of adequate training rather than very little or too aggressive training sessions.

Injury rates among sepak takraw and sport climbing athletes were very high, and it may be noted that these injury-prone games are included only in Asian Games; thus, we may suggest alterations in the game floor and use of more protective equipment.

- Regarding illnesses, the overall rate of illness was higher compared with earlier Olympics reports.

- Gastrointestinal problems were more frequent in contrast to other reports where respiratory issues were more common; in our report, respiratory issues stood next to gastrointestinal issues.

in physical activity is well known to reduce the risk of coronary heart disease, hypertension, obesity and diabetes mellitus. However, sports injuries and illnesses among athletes have also led to temporary or permanent morbidity. ${ }^{12}$ Standardised monitoring and evaluation of sports injury has been developed to provide not only epidemiological information on how injury occurs but also knowledge for its preventive measures. van Mechelen et al described these measures 
as the 'sequence of prevention'. ${ }^{3-5}$ The first step in the sequence of prevention is identification of the extent of injury, second the factors causing this injury, and third the measures to be taken to prevent injury. FIFA started injury surveillance in $1998,{ }^{5}$ which was then followed by other major events. ${ }^{6-9}$ The Korean Olympic Committee, formed in 1946, became a member of the IOC in 1947 and made their first appearance in London Olympic Games in $1948 .{ }^{10}$

The injury surveillance system developed by Junge et $a l^{11}$ convened by IOC was first successfully applied to multisport event during the 2008 Olympic Games, ${ }^{12}$ which later was extended to include injury as well as illness during the 2010 Vancouver Olympics ${ }^{13}$ and the subsequent Olympics. ${ }^{14-16}$

Although injury among athletes has been a main area of concern, the effects of illnesses cannot be overlooked. There is conclusive evidence that athletes in training are more susceptible to viral illnesses when compared with the normal population. ${ }^{17}$ Illnesses not only affect athletes' performance, but a transmittable illness could also affect sports competitors, trainers and even the audience. ${ }^{18} 19$ Moreover, the desire of athletes to train through illness to minimise lay-off time conflicts with the need to minimise stress during acute illness. ${ }^{17}$

Various studies have reported injury and illness patterns in Korean athletes over time. ${ }^{20-25}$ Most of these studies were performed over a long period of training in different sports. The aim of the present study is to study the injury and illness patterns among elite Korean athletes who participated in the 2018 Asian Games held in Jakarta and Palembang, Indonesia.

\section{METHODS}

\section{Study design and implementation}

We employed the IOC surveillance system to record injuries and illnesses sustained by South Korean athletes during the 2018 Asian Games in this prospective cohort study. Three weeks prior to the games, the study objectives were explained to South Korean team physiotherapists, trainers and team coaches. All injuries and illnesses which occurred during training or competition were reported to the chief medical officer $(\mathrm{CMO})$ in real time using a South Korean free instant messaging client called 'Kakao Talk' and the reported athletes were examined and treated by the CMO.

Injuries and illnesses were recorded in a standardised injury and illness form adopted from IOC. ${ }^{7}$ Anonymity and confidentiality were assured to all participants. Athletes' accreditation number was used to eliminate duplicate entries.

\section{Definition of injury and illness}

An injury is defined as any musculoskeletal complaint, concussion or other medical conditions newly incurred due to competition and/or training that received medical attention regardless of the consequences with respect to absence from competition and/or training. ${ }^{11}$
This excluded pre-existing and not fully rehabilitated injuries, but included all injuries that required medical attention and fully rehabilitated injuries that occurred during training and games.

An illness is defined as any physical complaint (not related to injury) newly incurred during games that received medical attention regardless of the consequences with respect to absence from competition and/ or training. ${ }^{11}$ This excluded pre-existing and chronic illnesses, but included all illnesses that required medical attention and acute exacerbations of chronic illness.

\section{Data analysis}

Injury and illness incidence rates were calculated using the formula $\mathrm{I}=\mathrm{n} / \mathrm{e}$, where $\mathrm{n}$ is the total number of injury and illness and $\mathrm{e}$ is the total number of exposed athletes. The 95\% CI for each rate was based on the Poisson distributed variable. The incidence of injury and illness was expressed per 100 athletes. Comparisons of categorical variables were done using $\chi^{2}$ test or Fisher's exact test for small numbers. Incidence rates between the two groups were presented as rate ratio (RR). We considered $\mathrm{p} \leq 0.05$ as significant. All data were evaluated using Microsoft Excel and SPSS V.14.0.

\section{Patient and public involvement}

Patients and/or the public were not involved in the design, or conduct, or reporting or dissemination plans of this research.

\section{RESULTS}

A total of 782 Korean athletes took part in the 2018 Asian Games held in Jakarta and Palembang in Indonesia from 18 August 2018 to 2 September 2018 (16 days), of whom $440(56.26 \%)$ were male and $342(43.73 \%)$ were female athletes.

\section{Incidence and distribution of injury}

We observed a total of 141 injuries, giving an injury rate of 18.03 per 100 athletes, out of which 121 (15.47\%) suffered at least one injury, $18(2.30 \%)$ suffered two injuries each and one athlete suffered triple injury. Out of 141 injuries $80(56.74 \%)$ were in male and $61(43.26 \%)$ were in female athletes. The risk of an athlete being injured was highest in sepak takraw $(n=17,62.96 \%)$, followed by sport climbing $(\mathrm{n}=8,57.14 \%)$. The risk of injury was high in basketball, bowling, fencing, field hockey, handball, jet ski, ju-jitsu, kabaddi, roller sports, rowing, squash, triathlon, weightlifting and wushu $(20 \%-50 \%$ of registered athletes were affected in each sport). No injuries were reported in archery, badminton, diving, equestrian, golf, gymnastics, karate, kurash, modern pentathlon, paragliding and water polo (table 1 and figure 1 ).

\section{Statistics}

The rate of injury in male (18.18 per 100 athletes, $95 \%$ CI 11.44 to 28.45 ) and female (17.84 per 100 athletes, $95 \%$ CI 10.67 to 27.22 ) athletes was similar. There was no statistical difference between the two groups $(\mathrm{RR}=1.01$, 


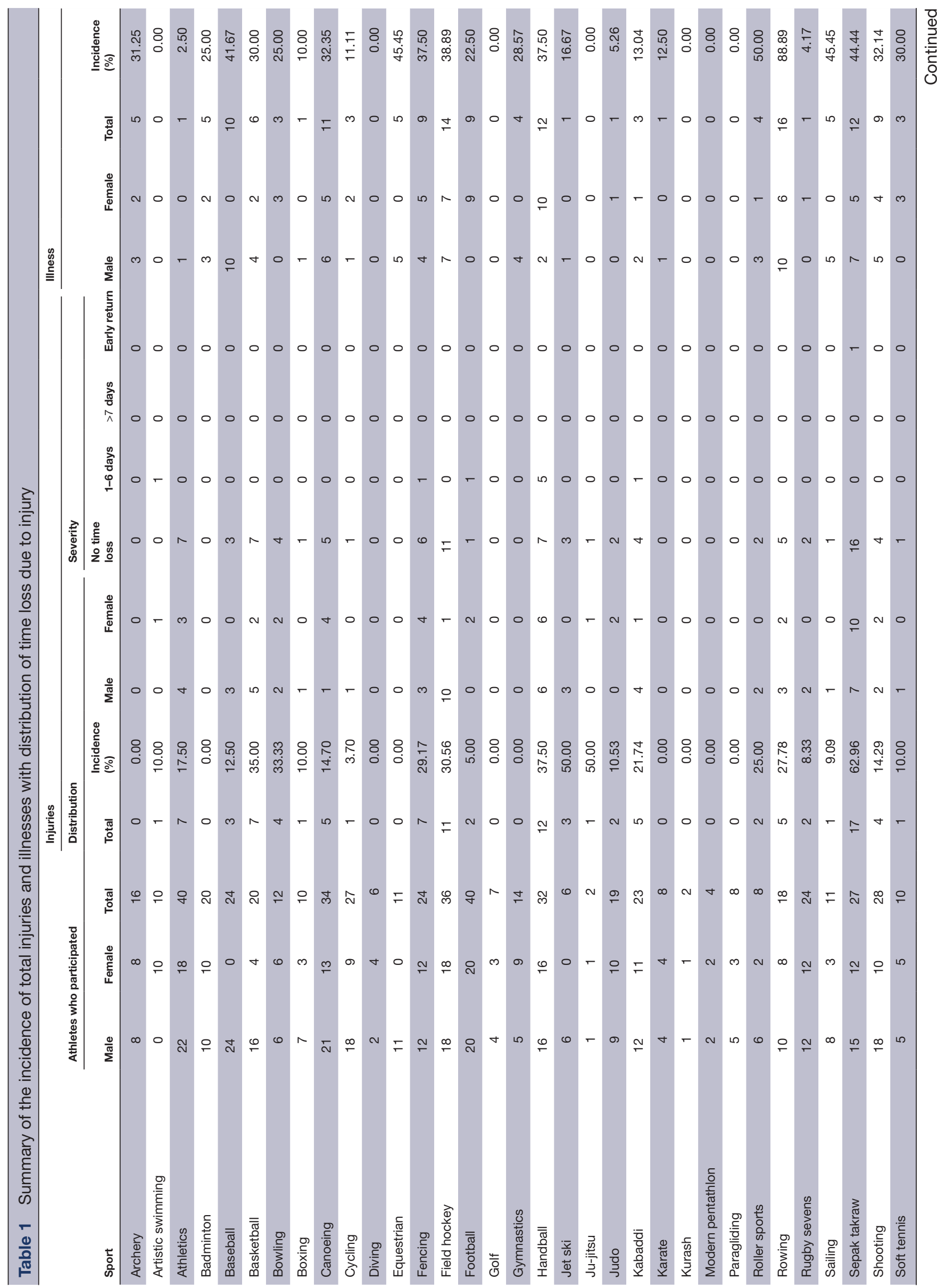




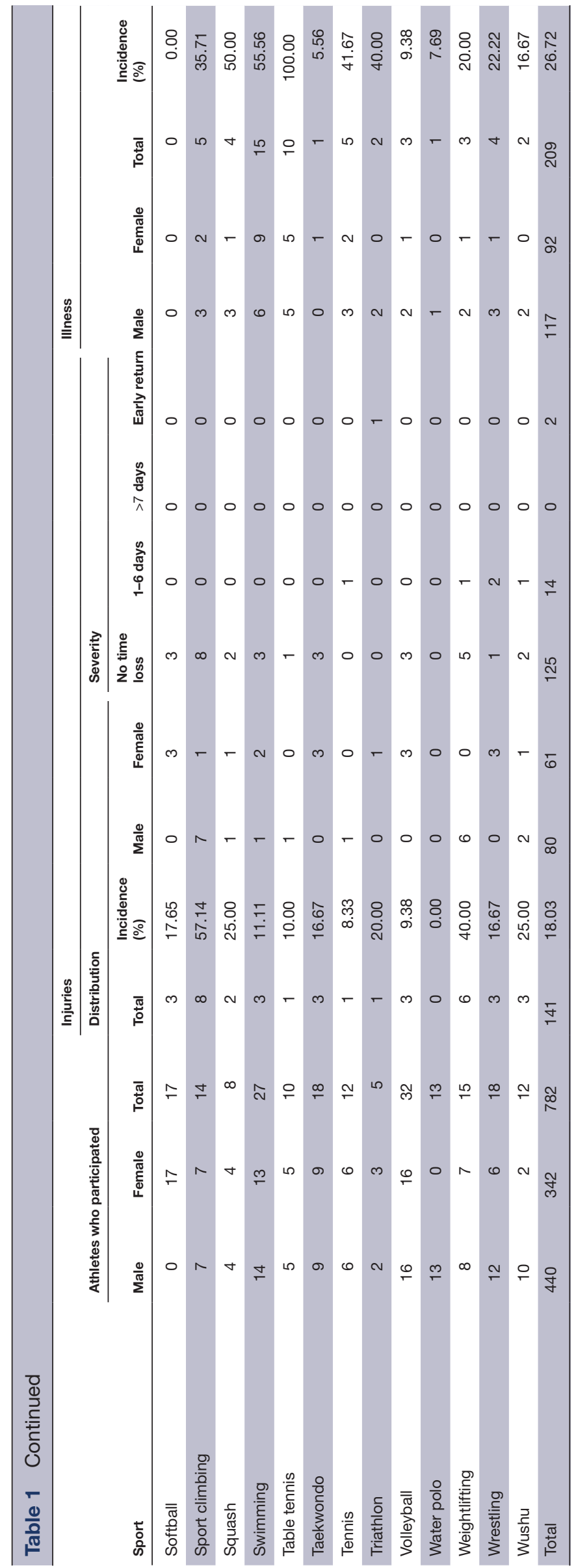


Injury and IIIness - Incidence

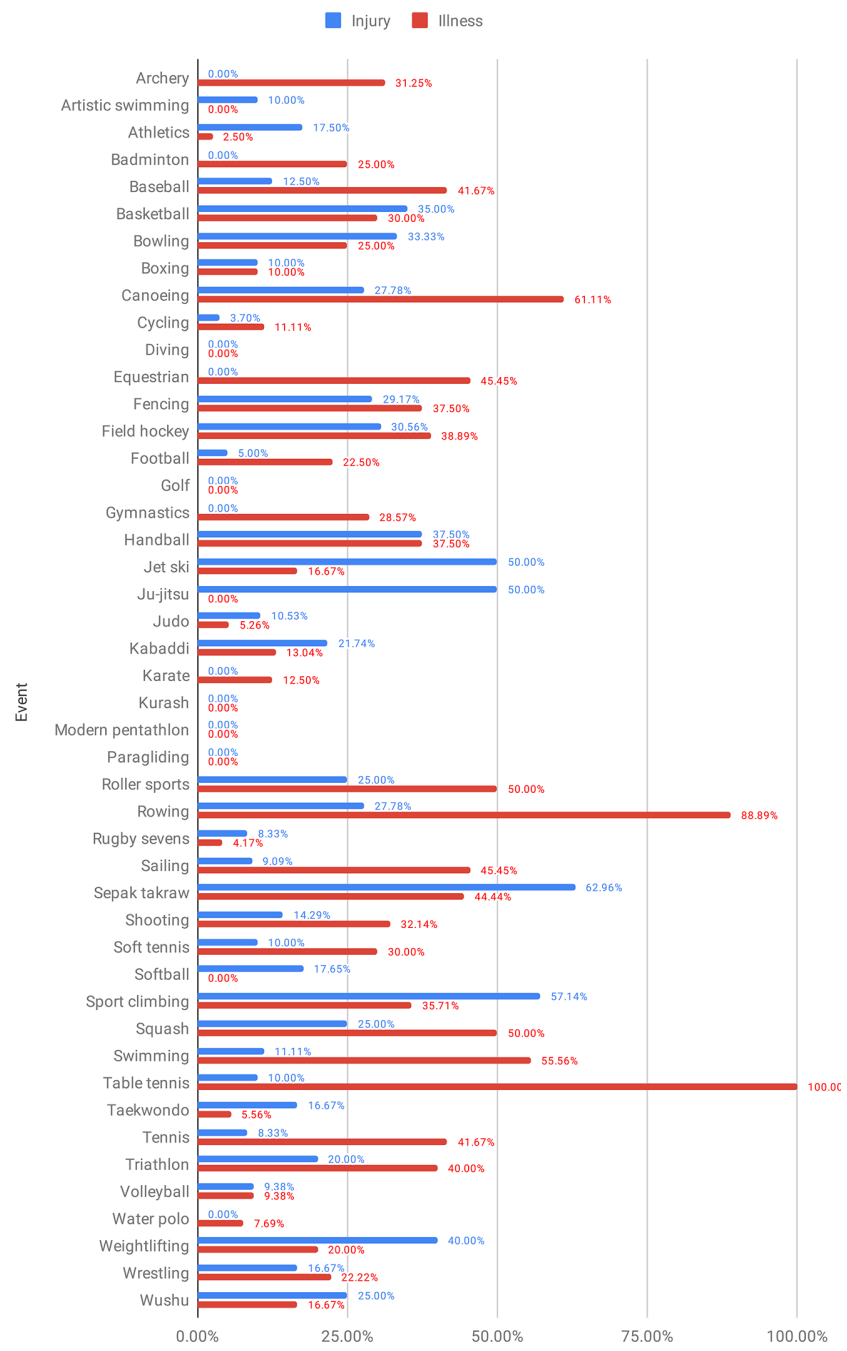

Figure 1 Graphical representation of the incidence of injuries and illnesses in different sport events.

$\mathrm{p}=0.901)$. However, male athletes were at significantly increased risk of injury in field hockey $(p=0.003)$, sport climbing $(p=0.005)$ and weightlifting $(p=0.007)$, whereas female athletes were at higher risk of injury in wrestling $(p=0.025)$.

\section{Severity}

Majority $(125,88.65 \%)$ of the athletes returned to their sports with no time loss, while $14(9.93 \%)$ athletes lost less than 7 days and 2 female $(1.42 \%)$ athletes had to return to their home country before their event. Both the two female athletes who returned earlier suffered ligament rupture, knee in one and ankle in the other, due to non-contact trauma.

\section{Circumstances}

Most of the injuries (65 of 141, 46.10\%) occurred during the time of training, followed by $28(19.86 \%)$ injuries during the time of competition. Only one $(0.71 \%)$ injury occurred during warm-up.

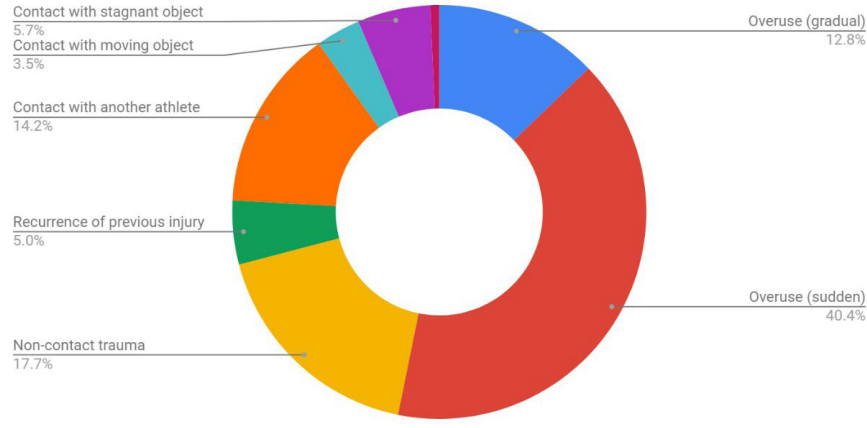

Figure 2 Cause of injury.

Location, cause and diagnosis of injury

Lower lumbar spine was injured in 25 (16.67\%) cases, followed by knee in 23 cases $(15.33 \%)$ and ankle in 16 cases $(10.67 \%)$. The abdomen, upper arm and hip were not injured.

The more frequently observed cause was overuse (sudden onset) in 57 cases $(40.42 \%)$, followed by noncontact trauma in 25 cases $(17.70 \%)$ (figure 2$)$. The least reported causes were violation of rules (obstruction, pushing), field of play conditions, weather conditions and equipment failure, with no cases in each.

The most common diagnosis of muscle strain/rupture/ tear was made in 42 cases (28.77\%), followed by ligament sprain in 30 cases $(20.55 \%)$ (figure 3$)$. Tendon rupture, joint dislocation, joint subluxation, arthritis, synovitis, bursitis, dental injury, neurological injury, spinal injury and others were not found to be causative in our series.

\section{Incidence and distribution of illness}

Among a total of 782 athletes, 209 (26.72\%) illnesses were reported; at least one illness was reported in 170 (21.73\%) athletes and double illness in 39 (4.98\%) athletes. Out of 209 illnesses 117 (26.59\%) were in male and $92(26.90 \%)$ were in female athletes. The maximum incidence of illness was reported in table tennis $(100 \%)$, followed by rowing $(94.44 \%)$. The risk of illness was also high in archery, baseball, basketball, canoeing, equestrian, fencing, field hockey, handball, tennis, sailing, shooting, squash and swimming (30\%-60\% of registered athletes in each sport) (table 1). No illness was reported in artistic swimming, diving, golf, jet ski, ju-jitsu, kurash, modern pentathlon, paragliding, softball and water polo. The maximum number of illnesses was reported on the fourth day of event $(n=22,10.52 \%)$.

\section{Statistics}

The rate of illness among female athletes (26.90 per 100 female athletes, $95 \%$ CI 17.79 to 38.10 ) was comparable with the rate of illness in male athletes (26.59 per 100 male athletes, $95 \%$ CI 17.79 to 38.09 ). There was no statistical difference between the two groups $(R R=0.98$, $\mathrm{p}=0.923)$. Female athletes in football were at significantly higher risk of falling ill $(\mathrm{p}=0.001)$. 


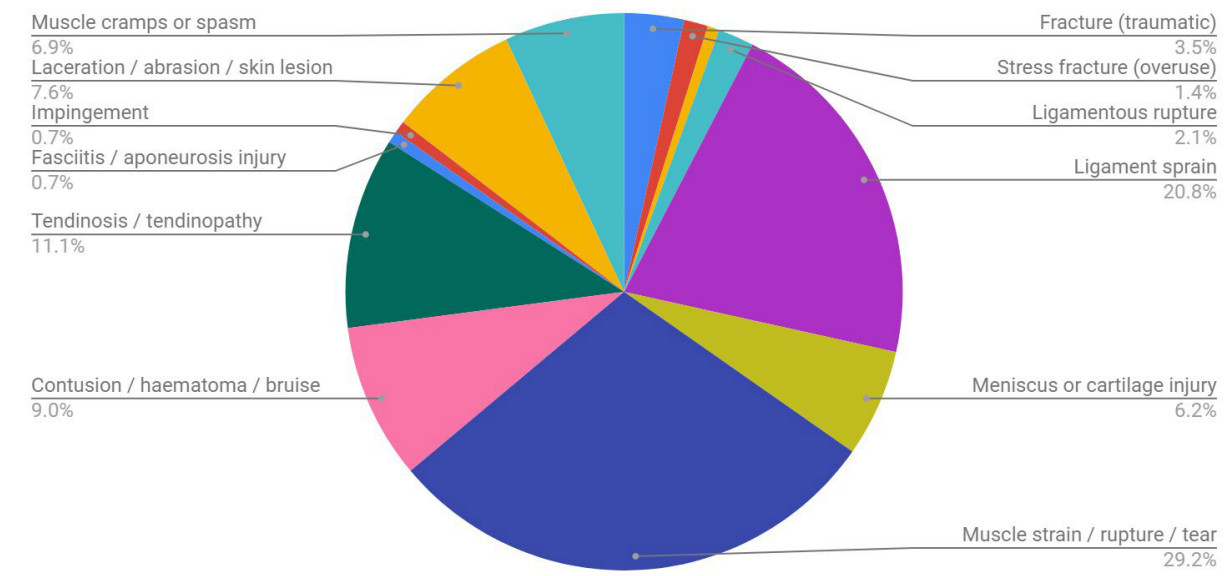

Figure 3 Diagnoses.

Affected system, symptom and cause of illness

The most common system involved was gastrointestinal $(\mathrm{n}=93,44.49 \%)$, followed by respiratory $(\mathrm{n}=53,25.36 \%)$. Out of 93 athletes complaining of gastrointestinal problems, $37(39.78 \%)$ were male and $56(60.21 \%)$ were female athletes; 83 of them reported gastrointestinal problems associated with diarrhoea/vomiting, 16 athletes had gastrointestinal problems associated with fever, and 42 athletes had associated pain in the abdomen (table 2). When gastrointestinal problem was plotted against the day of arrival, it was found that $32.25 \%$ of athletes complained of gastrointestinal problems on the fourth and fifth day of their arrival at the venue (figure 4). Change of environment was attributed to be the cause of gastrointestinal problem in 67 athletes $(72.04 \%)$ and infection in $24(25.80 \%)$.

Table 2 Distribution of presenting symptoms and causes of illness in two most affected systems (respiratory and gastrointestinal)

\begin{tabular}{|c|c|c|c|}
\hline Affected system & Respiratory & Gastrointestinal & Total \\
\hline \multicolumn{4}{|l|}{ Sex } \\
\hline Male & 23 & 37 & 60 \\
\hline Female & 30 & 56 & 86 \\
\hline Total & 53 & 93 & 146 \\
\hline \multicolumn{4}{|l|}{ Main symptom } \\
\hline Fever & 15 & 16 & 31 \\
\hline Pain & 46 & 42 & 88 \\
\hline Diarrhoea, vomiting & 0 & 83 & 83 \\
\hline Dyspnoea, cough & 13 & 0 & 13 \\
\hline Other & 0 & 2 & 2 \\
\hline Total & 74 & 143 & 217 \\
\hline \multicolumn{4}{|l|}{ Cause of illness } \\
\hline Infection & 50 & 24 & 74 \\
\hline Exercise-induced & 0 & 1 & 1 \\
\hline Environmental & 2 & 67 & 69 \\
\hline Other & 1 & 1 & 2 \\
\hline Total & 53 & 93 & 146 \\
\hline
\end{tabular}

The second most common system involved was respiratory $(\mathrm{n}=53,25.36 \%)$. Among 53 athletes with respiratory symptoms, 46, 15 and 13 presented with throat pain, fever and dyspnoea, respectively. Infection was attributed to be the cause in $50(94.33 \%)$ athletes. The maximum incidence of respiratory illness $(16.98 \%)$ was reported on the fifth day of event, whereas the maximum incidence of total illness was reported on the fourth day of event. Other systems involved were gynaecological in 4, cardio vascular system in 1 , allergic/immunological in 5 , neurological in 8 , dermatological in 25 and musculoskeletal in 12.

Of all illnesses, pain was the most common symptom $(\mathrm{n}=113,54.06 \%)$. Environmental factors were causative in 111 athletes $(53.11 \%)$ and infection in $79(37.79 \%)$. Illnesses resulted in loss of at least 1 day among 30 $(14.35 \%)$ athletes.

\section{DISCUSSION}

\section{Injury patterns during the 2018 Asian Games}

A total of 141 athletes were injured out of 782 athletes, giving an incidence of 18.03 athletes per 100 registered athletes. This incidence is higher when compared with the incidence in previous Olympic Games, Beijing 2008 $(9.61 \%),{ }^{12}$ Vancouver $2010(11.18 \%),{ }^{13}$ London 2012 $(12.88 \%),{ }^{14}$ Sochi $\left.2014(14 \%)\right)^{15}$ and Rio $2016(9.80 \%),{ }^{16}$ but lower compared with the Malaysian team in the 2014

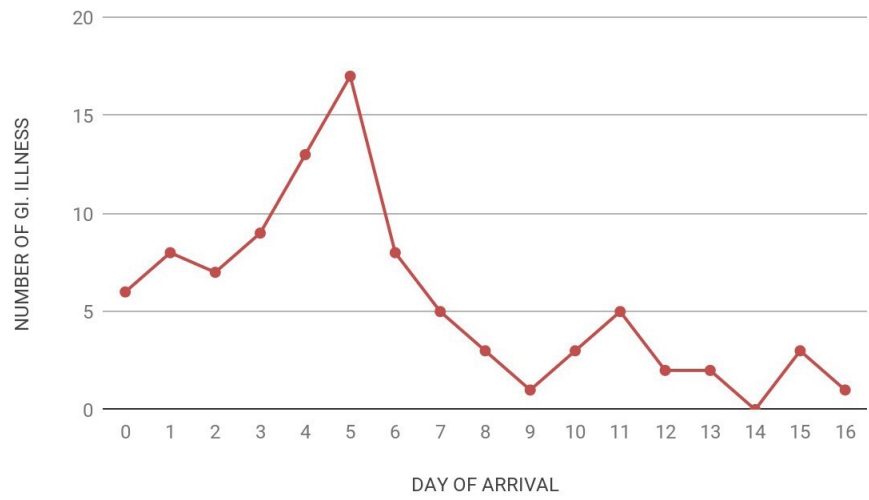

Figure 4 Distribution of gastrointestinal (GI) illness with respect to the nth day of their arrival at the venue. 
Asian Games (30\%). ${ }^{26}$ Earlier reports from the Olympic Games relied on voluntary reporting of injuries and illnesses by the athletes and submission by the medical officers of each country, which might not have uniformity and can have some bias based on individual perceptions of severity. This study is based on a single-physician (CMO) report. Each injury and illness was brought to notice irrespective of severity. Only the CMO decided whether the injury/illness must be reported or not.

In our study the rate of injury was higher in sepak takraw $(62.96 \%)$ and sport climbing $(57.14 \%)$. The higher incidence may be due to smaller study population when compared with previous Olympic reports. The higher rate of injury in our study can also be explained by our finding of higher rates of injury in sport climbing and sepak takraw; these injury-prone games are restricted to Asian Games only and are not included in the Olympics. Since the very nature of sepak takraw ${ }^{27} 28$ and sport climbing $^{29-32}$ is injury-prone, we therefore suggest better padded floorings and protective equipment for these games. With more than half of the players getting injured, we may suggest omission of such sports from Asian Games owing to the expenditure involved in taking care of them. However, such drastic conclusions cannot be made from few studies ${ }^{27-32}$ involving smaller groups of athletes and hence larger studies are required.

\section{Severity}

Out of the total injuries, majority $(n=125,88.65 \%)$ of the encounters did not result in any loss of days. The percentages of injuries which did not result in loss of days from sports were, respectively, $50.40 \%, 65 \%, 61 \%$ and $60 \%$ in Summer Olympics 2008, ${ }^{12}$ London Olympics 2012, ${ }^{14}$ Sochi 2014 Winter Olympics ${ }^{15}$ and Rio De Janeiro 2016 Olympics. ${ }^{16}$ Injury data from the Malaysian team in Asian Games reveal a closer injury severity with no time loss injuries of $68.70 \% .^{27}$

The higher incidence and more injuries with no time loss in our study population could be due to increased awareness among athletes to report even minor incidents and due to the cultural nature of perseverance to continue sports despite minor ailments. This also explains better rapport and compliance between athletes and medical personnel, more comprehensive and accurate reporting, and minimal or zero loss of injury coverage and data, which are vital in order not to miss any injury that can further harm the athletes and may prevent them from participating in sports.

Since the number of athletes injured with no loss of days is very high in our report, we therefore compared the athletes with severe injuries with the total number of athletes who participated rather than the number of athletes injured. In our study 2 out of 782 ( 0.26 per 100 or 2.6 per 1000 ) athletes had to return early due to severe injuries (one female athlete had ligament rupture in the knee and the other had ligament rupture in the ankle). We compared these data with athletes whose injuries cost them more than 28 days' time loss (considering them as severe injuries) to the total number of athletes who participated in the previous studies.
Agreeably, this was, respectively, 3.70, 6.50, 14.02 and 10.20 per 1000 registered athletes in Summer Olympics 2008, ${ }^{12}$ London Olympics 2012,14 Sochi 2014 Winter Olympics ${ }^{15}$ and Rio 2016 Olympics. ${ }^{16}$

\section{Circumstances}

More injuries occurred during training $(46.10 \%)$. This is almost closer to the injury circumstances (ie, during training) of the Malaysian team in 2014 Asian Games $(57 \%)^{26}$ and Sochi 2014 Winter Olympics $(63 \%),{ }^{15}$ whereas the majority of the injuries $(72.60 \%)$ occurred during competition in Summer Olympics 2008, ${ }^{12} 55 \%$ during competition in London Olympics $2012^{14}$ and $59 \%$ during competition in Rio 2016 Olympics. ${ }^{16}$ We are not sure of this gross variation in injury circumstances.

There is adequate evidence in the literature that both undertraining and overtraining can lead to increased injuries to the athletes. ${ }^{33}$ However adequate hard training actually improves physique, which protects from injuries. ${ }^{35}$ We also firmly believe that injuries during training can be reduced to a greater extent by balancing the intensity of training to appropriate levels ${ }^{36}$ just before the events and not to be overenthusiastic.

\section{Location, type and cause of injuries}

Lower lumbar spine was injured in $25(16.67 \%)$ cases, followed by knee in $23(15.33 \%)$ cases and ankle in 16 $(10.67 \%)$ cases. The most frequently observed type was muscle injuries, which occurred in $42(28.77 \%)$ cases, followed by sprains in $30(20.55 \%)$ cases. In Rio 2016 Olympics ${ }^{16}$ ligament injuries $(16.98 \%)$ and muscle injuries $(15.26 \%)$ were frequent, in agreement with our study.

The more frequently observed cause was overuse (sudden onset) in $57(40.40 \%)$ cases, followed by noncontact trauma in $25(17.70 \%)$ cases and contact with another athlete in $20(14.20 \%)$ cases. Overuse was causative in $25 \%$ in London 2012, ${ }^{14} 14 \%$ in Sochi $2014,{ }^{15} 19 \%$ among the Malaysian team in Asian Games ${ }^{26}$ and $19 \%$ in Rio 2016. ${ }^{16}$ Non-contact trauma was causative in $20 \%$ in London 2012, ${ }^{14} 13 \%$ in Sochi $2014^{15}$ and $21 \%$ in Rio 2016. ${ }^{16}$ Thus overuse and non-contact trauma were more frequently causative in other reports as well.

\section{IIIness risk during the 2018 Asian Games}

The overall rate of illness in our report was higher (26.72\%) when compared with previous reports, that is, in London $2012(7 \%),{ }^{14}$ Vancouver $2010(7 \%),{ }^{13}$ Sochi $2014(8 \%)^{15}$ and Rio 2016 (5\%). ${ }^{16}$ Higher illness incidence was reported by the Malaysian athletic team $(23.2 \%)^{26}$ during the 2014 Asian Games, the Korean Olympic team in Rio $(35.8 \%)^{37}$ and during the 2009 International Association of Athletics Federations World Athletics Championship (68.2\%). ${ }^{38}$ Like previous reports illness was slightly more common among female athletes as compared with male athletes (26.90 vs 26.59 per 100 athletes).

Gastrointestinal was the most common system involved $(44.49 \%)$ in contrast to previous events which reported respiratory as the most common system involved. Out of 
93 athletes with gastrointestinal problems, 83 presented with diarrhoea or vomiting. Runner's diarrhoea ${ }^{39}$ (runners trots) is a well-known complaint in athletes. Stuempfle $e t$ $a l^{39}$ in their study reported gastrointestinal distress in as high as $96 \%$ of endurance athletes. Although the exact mechanism is unknown, proposed theories are shunting of blood from the gut to the musculoskeletal system during exercise leading to disruption of the gastric barrier and diarrhoea ${ }^{40}$ increased jostling of abdominal contents during exercise causing altered transit time in small and large bowels, ${ }^{41}{ }^{42}$ decreased adaptability to changes in the environment, increased training stress, temperature changes during and after training, increased crowd in athletic village, and change in food types and water in a different country. Almost all cases of diarrhoea and vomiting responded to oral fluids and antimotility agents; 16 of them presented with fever and 42 with abdominal pain requiring medication, but none lasted for more than 48-72 hours.

Respiratory complaints were present in $25.36 \%$ of athletes, which was lower compared with $62.8 \%$ in Vancouver, $64 \%$ in Sochi, $47 \%$ in Rio, $51 \%$ in Malaysian athletes in the 2014 Asian Games and $75.9 \%$ in Korean Olympics team in Rio Olympics. Respiratory illness has always been on the higher side among athletes participating in multisport events. ${ }^{43-49}$ This increased incidence of respiratory illness has been attributed to increased inhalation of airborne pollutants and irritants during increased ventilatory exercises, dehydration of airway, immunosuppression following stress and performance pressure. ${ }^{50}$ Studies have anticipated that athletes travelling intercountry or intercontinental are at higher risk of contracting an illness. ${ }^{51}$

\section{Treatment and prevention}

Adequate oral fluids and antimotility agents such as loperamide relieve diarrhoea, and for athletes complaining of abdominal pain or haematochezia all non-steroidal anti-inflammatory drugs should be stopped and supplemented with $\mathrm{H} 2$ blockers. ${ }^{41} 52$

For prevention all athletes should be evaluated with adequate history of irritable bowel disease or any gastrointestinal-related conditions; although prewarming increases the performance of athletes, excessive body heat can cause decreased performance. ${ }^{53}$ de Oliveira et $a t^{42}$ in their study recommended fluid intake with multiple transportable carbohydrates such as glucose and fructose rather than hydration with only glucose. Another nutritional preventive measure proposed by Lis $e t a \tilde{p}^{4}$ is to avoid fermentable oligosaccharides, disaccharides, monosaccharides and polyols (FODMAPs). FODMAPs increase water and fermentable substrate within the colon. ${ }^{55}$

\section{Strengths and limitations}

The strength of this study is the comprehensive and $100 \%$ reporting of injuries and illnesses. Since the data collection and reporting was through a single physician, there was no bias in reporting of severity of injury and illness and even the trivial ones were notified to the CMO. Formation and use of social media-based group for communication was a new approach to this type of study which helped to prevent loss of data.

The smaller study population was a limitation of this study, which led to higher incidence of injuries and illnesses as compared with previous Olympic Games. Another limitation was that we did not report risk of injury and illness as a measure of time exposed owing to the fact that large numbers of participants had variable exposed days; thus, our method assumes that all participants were equally exposed to length and frequency of risks.

Time loss for injured athletes who had to return home early was based on how long he or she could not participate in training or competition. A follow-up of these athletes on how long it takes for them to recover and the percentage of recovery achieved could improve the validity of the data. Another suggestion is video analysis of all injuries for better understanding of the mechanism of injuries.

\section{CONCLUSION}

The incidence of injuries and illnesses among South Korean athletes in the 2018 Asian Games was 18.03 and 27.28 per 100 athletes, respectively. The rate of injuries and illnesses was affected by specific types of sports and gender. Most of the injuries and illnesses were minor, with no loss of participation. The highest number of injuries was recorded in sport climbing and sepak takraw, while the highest number of illnesses was reported in table tennis and rowing.

Contributors S-HL conceived the idea of the study and design of the work, assisted by SK, MB and JY with data collection. RJ and MMS helped in the analysis of the collected data and in drafting of the manuscript. DYL made critical revision to the manuscript. All authors made approval of the final manuscript as submitted.

Funding The authors have not declared a specific grant for this research from any funding agency in the public, commercial or not-for-profit sectors.

Competing interests None declared.

Patient consent for publication Not required.

Provenance and peer review Not commissioned; externally peer reviewed.

Data availability statement Data are available upon reasonable request.

Open access This is an open access article distributed in accordance with the Creative Commons Attribution Non Commercial (CC BY-NC 4.0) license, which permits others to distribute, remix, adapt, build upon this work non-commercially, and license their derivative works on different terms, provided the original work is properly cited, appropriate credit is given, any changes made indicated, and the use is non-commercial. See: http://creativecommons.org/licenses/by-nc/4.0/.

\section{ORCID iDs}

Sang-Hoon Lhee http://orcid.org/0000-0001-8881-7506

Mohanraj Madathur Sadasivam http://orcid.org/0000-0003-2383-7316

Sejun Kim http://orcid.org/0000-0002-3417-7969

Jungjin Yu http://orcid.org/0000-0002-0371-6851

Do Young Lee http://orcid.org/0000-0002-5868-2628

\section{REFERENCES}

1 Bahr R, Holme I. Risk factors for sports injuries--a methodological approach. Br J Sports Med 2003;37:384-92.

2 Fuller CW, Junge A, Dvorak J. A six year prospective study of the incidence and causes of head and neck injuries in international football. Br J Sports Med 2005;39 Suppl 1:i3-9.

3 Meeuwisse WH, Love EJ. Athletic injury reporting. Sports Medicine 1997;24:184-204. 
4 van Mechelen W, Hlobil H, Kemper HC. Incidence, severity, aetiology and prevention of sports injuries. A review of concepts. Sports Med 1992;14:82-99.

5 Junge A, Dvorak J, Graf-Baumann T, et al. Football injuries during FIFA tournaments and the Olympic Games, 1998-2001: development and implementation of an injury-reporting system. Am J Sports Med 2004;32:80-9.

6 Bahr R, Reeser JC, Fédération Internationale de Volleyball. Injuries among world-class professional beach volleyball players. The Fédération Internationale de Volleyball beach volleyball injury study. Am J Sports Med 2003;31:119-25.

7 Fuller CW, Laborde F, Leather RJ, et al. International rugby board rugby world cup 2007 injury surveillance study. Br J Sports Med 2008;42:452-9.

8 Hägglund M, Waldén M, Bahr R, et al. Methods for epidemiological study of injuries to professional football players: developing the UEFA model. Br J Sports Med 2005;39:340-6.

9 Webborn N, Willick S, Reeser JC. Injuries among disabled athletes during the 2002 winter Paralympic Games. Med Sci Sports Exerc 2006;38:811-5.

10 Korea Sports. Korea Sports \& Olympic Committee. Available: https:// www.sports.or.kr

11 Junge A, Engebretsen L, Alonso JM, et al. Injury surveillance in multi-sport events: the International Olympic Committee approach. Br J Sports Med 2008;42:413-21.

12 Junge A, Engebretsen L, Mountjoy ML, et al. Sports injuries during the summer Olympic Games 2008. Am J Sports Med 2009;37:2165-72.

13 Engebretsen L, Steffen K, Alonso JM, et al. Sports injuries and illnesses during the winter Olympic Games 2010. Br J Sports Med 2010;44:772-80.

14 Engebretsen L, Soligard T, Steffen K, et al. Sports injuries and illnesses during the London summer Olympic Games 2012. Br J Sports Med 2013;47:407-14.

15 Soligard T, Steffen K, Palmer-Green D, et al. Sports injuries and illnesses in the Sochi 2014 Olympic winter games. Br J Sports Med 2015;49:441-7.

16 Soligard T, Steffen K, Palmer D, et al. Sports injury and illness incidence in the Rio de Janeiro 2016 Olympic summer games: a prospective study of 11274 athletes from 207 countries. Br J Sports Med 2017;51:1265-71.

17 Roberts JA. Viral illnesses and sports performance. Sports Med 1986;3:296-303.

18 Ahmadinejad Z, Alijani N, Mansori S, et al. Common sports-related infections: a review on clinical pictures, management and time to return to sports. Asian J Sports Med 2014;5:1-9.

19 Roberts JA, Wilson JA, Clements GB. Virus infections and sports performance--a prospective study. Br J Sports Med 1988;22:161-2.

20 Yang YJ, Lee JH, LEe MJ. Injuries and illnesses of Korean athletes during 2002 Busan Asian games. Korean J Sports Med 2004;22:135-43.

21 Kim E, Kim T, Park W. Injuries at the summer Asian games 2010: a prospective epidemiologic study in national athletes. Int SportMed $J$ 2014;15:62-76.

22 Lee CY. The sport injuries of Korean national male and female ice hockey players. Korean J Phys Educ 2007;46:473-84.

23 Park KJ, Brian Byung S, Byung SB. Injuries in elite Korean fencers: an epidemiological study. Br J Sports Med 2017;51:220-5.

24 Son BA, Jeong HS, Kong ID, et al. Epidemiological study of taekwondo injuries: 1-year prospective study. Br J Sports Med 2017;:51:391

25 Cho YJ, Na YM, Jung HS, et al. One-Year follow-up prospective epidemiological study of injury types in the Korea ladies professional golfers, 2015 season. Br J Sports Med 2017;51:307

26 AHamid MS, Puji A, Salleh Z. Patterns of injuries and illness among Malaysian athletes during the XVII Asian games 2014. Sains Malaysiana 2016;45:1531-153.

27 Jalayondeja W, Vatchalathiti R, Neraphong K. Injuries in Thai male national Sepaktakraw team: 13th Asian games tournament. Hong Kong, China: International symposium in biomechanics in sports, 2000.

28 Kerdsomnuk P, Limroongreungrat W, Chaunchaiyakul R. Ground reaction force and loading rate during sepaktakraw spike landings. $J$ Sports Sci 2015;15.

29 Grønhaug G, Norberg M. First overview on chronic injuries in sport climbing: proposal for a change in reporting of injuries in climbing. BMJ Open Sport Exerc Med 2016;2:e000083.
30 Grønhaug G. Self-Reported chronic injuries in climbing: who gets injured when? BMJ Open Sport Exerc Med 2018;4:e000406.

31 Woollings KY, McKay CD, Emery CA. Risk factors for injury in sport climbing and bouldering: a systematic review of the literature. $\mathrm{Br} J$ Sports Med 2015;49:1094-9.

32 Paige TE, Fiore DC, Houston JD. Injury in traditional and sport rock climbing. Wilderness Environ Med 1998:9:2-7.

33 Orchard $\mathrm{J}$. Who is to blame for all the football injuries? $\mathrm{Br} \mathrm{J}$ sports Med, 2012. Available: http://blogs.bmj.com/bjsm/2012/06/20/whois-to-blame-for-all-thefootball-injuries/

34 Soligard T, Schwellnus M, Alonso J-M, et al. How much is too much? (Part 1) International Olympic Committee consensus statement on load in sport and risk of injury. $\mathrm{Br} J$ Sports Med 2016;50:1030-41.

35 Gabbett TJ. The training-injury prevention paradox: should athletes be training smarter and harder? Br J Sports Med 2016;50:273-80.

36 Morton RH. Modeling training and overtraining. J Sports Sci 1997;15:335-40.

37 Yoon J, Bae M, Kang H, et al. Descriptive epidemiology of sports injury and illness during the Rio 2016 Olympic games: a prospective cohort study for Korean team. Int J Sports Sci Coach 2018;13:939-46.

38 Alonso J-M, Tscholl PM, Engebretsen L, et al. Occurrence of injuries and illnesses during the 2009 IAAF world athletics Championships. Br J Sports Med 2010;44:1100-5.

39 Stuempfle KJ, Hoffman MD. Gastrointestinal distress is common during a 161-km ultramarathon. J Sports Sci 2015;33:1814-21.

40 de Oliveira EP. Runner's diarrhea: what is it, what causes it, and how can it be prevented? Curr Opin Gastroenterol 2017;33:41-6.

41 Moses FM. The effect of exercise on the gastrointestinal tract. Sports Med 1990;9:159-72.

42 de Oliveira EP, Burini RC, Jeukendrup A. Gastrointestinal complaints during exercise: prevalence, etiology, and nutritional recommendations. Sports Med 2014;44 Suppl 1:79-85.

43 Schwellnus M, Derman W, Jordaan E, et al. Factors associated with illness in athletes participating in the London 2012 Paralympic games: a prospective cohort study involving 49,910 athlete-days. $\mathrm{Br}$ J Sports Med 2013;47:433-40.

44 Derman W, Schwellnus M, Jordaan E, et al. Illness and injury in athletes during the competition period at the London 2012 Paralympic games: development and implementation of a webbased surveillance system (WEB-IISS) for team medical staff. $\mathrm{Br} \mathrm{J}$ Sports Med 2013;47:420-5.

45 Dvorak J, Junge A, Derman W, et al. Injuries and illnesses of football players during the 2010 FIFA World cup. Br J Sports Med 2011;45:626-30.

46 Alonso J-M, Edouard P, Fischetto G, et al. Determination of future prevention strategies in elite track and field: analysis of Daegu 2011 IAAF Championships injuries and illnesses surveillance. Br J Sports Med 2012;46:505-14.

47 Sell K, Hainline B, Yorio M, et al. Illness data from the US open tennis Championships from 1994 to 2009. Clin J Sport Med 2013;23:25-32.

48 Al-Shaqsi S, Al-Kashmiri A, Al-Risi A, et al. Sports injuries and illnesses during the second Asian beach games. Br J Sports Med 2012;46:780-7.

49 Theron N, Schwellnus M, Derman W, et al. Illness and injuries in elite football players--a prospective cohort study during the FIFA Confederations Cup 2009. Clin J Sport Med 2013;23:379-83.

50 Kippelen P, Fitch KD, Anderson SD, et al. Respiratory health of elite athletes - preventing airway injury: a critical review. Br J Sports Med 2012; $46: 471-6$

51 Schwellnus MP, Derman WE, Jordaan E, et al. Elite athletes travelling to international destinations $>5$ time zone differences from their home country have a 2-3-fold increased risk of illness. Br J Sports Med 2012;46:816-21.

52 Cooper BT, Douglas SA, Firth LA, et al. Erosive gastritis and gastrointestinal bleeding in a female runner. prevention of the bleeding and healing of the gastritis with $\mathrm{H} 2$-receptor antagonists. Gastroenterology 1987;92:2019-23.

53 Koon G, Atay O, Lapsia S. Gastrointestinal considerations related to youth sports and the young athlete. Trans/ Pediatr 2017;6:129-36.

54 Lis D, Ahuja KDK, Stellingwerff T, et al. Food avoidance in athletes: FODMAP foods on the list. Appl Physiol Nutr Metab 2016:41:1002-4.

55 Barrett JS, Gearry RB, Muir JG. Dietary poorly absorbed, short-chain carbohydrates increase delivery of water and fermentable substrates to the proximal colon. Aliment Pharmacol Ther 2010;31:874-82. 